\title{
QUANTITATIVE GENETIC ANALYSIS OF TOTAL GLUCOSINOLATE, OIL AND PROTEIN CONTENTS IN ETHIOPIAN MUSTARD (BRASSICA CARINATA A. BRAUN)
}

\author{
Nigussie Alemayehu ${ }^{1}$ and Heiko Becker ${ }^{2}$ \\ ${ }^{1}$ Holetta Agricultural Research Center, Ethiopian Agricultural Research Organization \\ PO Box 2003, Addis Ababa, Ethiopia. E-mail: nalemayehua@yahoo.com \\ 2 Institute of Agronomy and Plant Breeding, Georg August University, Von-Siebold Str-8, 37075 \\ Goettingen, Germany. E-mail: hbecker1@gwdg.de
}

\begin{abstract}
Cultivars of Ethiopian mustard are agronomically robust, but have very high levels of total glucosinolates, which impair feed value of the meal though it is rich in protein of balanced amino acids. This experiment was undertaken to assess the level of natural variation in total glucosinolate, and study its inheritance together with that of oil and protein from a diallel cross of six inbred lines which were field-tested in a randomized block design at two locations in Ethiopia. Seeds were analyzed using HPLC (glucosinolates), NMR (oil) and NIRS (protein). Analyses of variance, Hayman's method of diallel analysis and a mixed linear model of genetic analysis were employed to estimate and predict genetic parameters and interactions. There were significant differences among the parental lines as well as their hybrids. The additive, dominance and cytoplasmic effects were highly significant for all the traits. The additive component of variance, accounting for about $40 \%$ of the total variations in all the traits, was twice as much as the dominance, which in turn was also about twice as much as the variation accounted by the cytoplasm. A clear-cut case of inbreeding depression was evident with oil content. Partial dominance was most prevalent in governing total glucosinolate although some levels of overdominance were also noticed. It appeared that in addition to nuclear genes, cytoplasmic components, which could be persistent or transient maternal effects, are also of significance in the inheritances of these quantitative traits in B. carinata. There were at least two dominant genes with decreasing effect on total glucosinolate for every single recessive gene of counter actions. The predominant additive component of variation coupled with the high narrow-sense heritability may allow fixation of low levels of total glucosinolate in recombinant inbred lines by selection.
\end{abstract}

Key words/phrases: Brassica carinata, diallel cross, glucosinolates, oil, protein

\section{INTRODUCTION}

Production of Ethiopian mustard (Brassica carinata A. Braun) in the plateaus of Ethiopia has been a culture of antiquity (Shigesaburo-Tsunoda, 1980; Gomez-Campo and Prakash, 1999). Today this crop stands only as the third among a long-list of crop species known to bear edible or industrial oils in Ethiopia (Seegler, 1983). The meal after extraction of the oil, although rich in protein of balanced amino acids, is characterized by a very high content of sinigrin (Roebbelen and Thies, 1980b; Becker et al., 1999), which belongs to the group of secondary plant products collectively called glucosinolates (Kjaer, 1976; Underhill, 1980; Sorensen, 1981), which in turn are generally considered as anti-nutritional constituents especially to monogastric animals (Bell and Williams, 1953; Roebbelen, 1981; Sarwar et al.,
1981; Bell and Shires, 1982; Bourdon and Aumaitre, 1990; Downey, 1990; Bell, 1993).

Because of the anti-nutritional effects of glucosinolates, oil-pressing industries in Ethiopia virtually dispose the meal to be used only for fuel. This, however, is not economically affordable nor is it acceptable in the face of ever diminishing grazing land and serious shortage of protein supplement. Therefore, developing cultivars of $B$. carinata with a reduced glucosinolate content of an innocuous level but with a concomitant increase of the oil and protein contents by plant breeding is an extremely pressing need. Experiences with other brassica species show that it is possible to develop low-glucosinolate cultivars by continuous single plant selection (Roebbelen and Thies, 1980b). This experiment was, therefore, undertaken to assess, the extent of variability in total glucosinolate naturally available in the germplasm and that could be attained from recombinant lines 
developed by hybridization and selection and study its inheritance so that the promises of genotypes with low levels of the trait but high levels of oil and protein contents can be foretold.

\section{MATERIALS AND METHODS}

Six inbred lines with contrasting levels of total glucosinolate content have been developed by subsequent selfing (up to $\mathrm{F}_{4}$ ) and selection of single plants from material of Ethiopian origin in the Institute of Agronomy and Plant Breeding, Goettingen, Germany. Three of the lines (1, 2 and $5)$ were developed as low-glucosinolate parents and the other three lines (3, 4 and 6) as highglucosinolate parents. A full diallel crossing was made among these lines and all the $30 \mathrm{~F}^{\prime} \mathrm{s}$ and their six parental selfs were field-tested at two locations (Holetta and Kulumsa) in Ethiopia during the main cropping season of 1999. Holetta $\left(38^{\circ} \mathrm{E}\right.$ and $\left.{ }^{9} \mathrm{~N}\right)$ is a high-altitude $(2400 \mathrm{~m})$ and high-rainfall (1200 $\mathrm{mm} /$ annum) area with a relatively suitable extended growing period; and Kulumsa $\left(39^{\circ} \mathrm{E}\right.$ and $\left.8^{\circ} \mathrm{N}\right)$ is a medium altitude $(2190 \mathrm{~m})$ and medium-high rainfall (750 $\mathrm{mm}$ /annum) area with shorter growing period. The experiment was laid out in a randomized complete block design with two replications. The plot size was $2.4 \mathrm{~m}^{2}$ of four rows with $30 \mathrm{~cm}$ interrow spacing and $2 \mathrm{~m}$ length. There were 20 equally spaced plants in each row first attained by placing three seeds per hill at a regular interval of $10 \mathrm{~cm}$ at sowing and later after establishment, by letting only one of the seedlings to grow while thinning out the rest. In case where all the three seeds failed to succeed, missing hills were filled up by transplanting the excess from other rows. Crop management practices like land preparation, crop rotation, fertilizer and weed control were maintained as recommended for each location.

Total glucosinolate content ( $\mu$ moles/g of seed) was determined as the sum of individual glucosinolates on a single-plot basis using HighPerformance Liquid Chromatography (HPLC). Oil content was determined by Nuclear Magnetic Resonance (NMR) according to Madson (1976) and protein content by Near Infrared Reflectance Spectroscopy (NIRS) according to Velasco et al. (1995). Analysis of variance was made with the PLABSTAT (Utz, 1991). Group-comparisons were made according to Gomez and Gomez (1984). Estimation and prediction of genetic parameters, variance components and interactions were made using a mixed linear model developed by Zhu and
Weir (1994) for the analyses of diallel crosses and their environmental interactions, in which

$$
y=\mu+L+A+D+C+A L+D L+C L+B+\varepsilon
$$

where $\mu=$ general mean; $\mathrm{L}=$ location, $\mathrm{A}=$ additive, $\mathrm{D}=$ dominance, $\mathrm{C}=$ cytoplasmic and $\mathrm{B}=$ within location block effects; and $\varepsilon=$ residual. Hayman's method of diallel analysis as described by Singh and Chaudhary (1977) has been used to estimate various genetic parameters for total glucosinolate by combining the data from the two locations. In this method,

The additive component of variation

$$
\text { (D) }=\text { VoLo-E }
$$

The dominance component of variation

$$
H_{1}=\frac{V o L o_{1}-4 W o L o_{1}+4 V_{1} L_{1}-(3 n-2) E}{n}
$$

The average covariance of the additive and dominance effects of arrays

$$
F=\frac{2 V o L o-4 W o L o_{1}-2(n-2) E}{n}
$$

A parameter used to determine frequencies of genes with positive and negative effects

$$
H_{2}=4 V_{1} L_{1}-4 V o L_{1}-2 E
$$

The expected environmental component of variation

$$
E=\frac{\text { error SS + replication SS + locationSS }}{\mathrm{df}(\text { error }+ \text { replication + location })} *(r l=2 * 2=4)
$$

Proportion of dominant and recessive genes

$$
\frac{K_{d}}{K_{r}}=\frac{\left(\sqrt{4 D^{*} H_{1}}\right)+F}{\left(\sqrt{4 D^{*} H_{1}}\right)-F}
$$

Narrow-sense heritability

$$
h^{2}=\frac{0.5 D+0.5 H_{1}-0.5 H_{2}-0.5 F}{0.5 D+0.5 H_{1}-0.25 H_{2}-0.5 F+E}
$$

The test statistic " $\mathrm{t}$ " tested against table value of $\mathrm{F}$ with 4 and n-2 degrees of freedom

$$
t^{2}=\frac{(n-2)}{4} \frac{\left(\operatorname{var} V_{r}-\operatorname{var} W_{r}\right)^{2}}{\operatorname{var} V_{r} * \operatorname{var} W_{r}}-\operatorname{Cov}^{2}\left(V_{r}, W_{r}\right)
$$

where

$\mathrm{Vr}=$ variance of each array;

$\mathrm{Wr}=$ covariance between parents and their offspring;

VoLo=variance of parents;

$\mathrm{VoL}_{1}=$ variance of the mean of arrays;

$\mathrm{V}_{1} \mathrm{~L}_{1}=$ mean variance of the arrays;

$\mathrm{WoLo}_{1}=$ mean covariance between parents and their offspring; and $\mathrm{n}=6$ (number of parental lines). 
The coefficient of correlation between the parental order of dominance $(\mathrm{Wr}+\mathrm{Vr})$ and parental mean $(\mathrm{Yr})=\mathrm{r}$

The regression coefficient, $b=\frac{\operatorname{cov}(W r, V r)}{\operatorname{var}(V r)}$

The average degree of dominance $=\sqrt{\frac{H_{1}}{H_{2}}}$

In order to test each of the components, first a common multiplier or variance $\left(\mathrm{S}^{2}\right)$ was calculated as: $s^{2}=0.5 \operatorname{Var}\left(W_{r}-V_{r}\right)$ and then a specific multiplier for each component was calculated. For

$\mathrm{D}, \frac{\mathrm{n}^{5}+\mathrm{n}^{4}}{\mathrm{n}^{5}}$; for $\mathrm{F}, \frac{4 \mathrm{n}^{5}+20 \mathrm{n}^{4}-16 n^{3}+16 n^{2}}{\mathrm{n}^{5}}$; for $\mathrm{H}_{1}, \frac{\mathrm{n}^{5}+41 \mathrm{n}^{4}-12 n^{3}+4 n^{2}}{\mathrm{n}^{5}} ;$ for $\mathrm{H}_{2}$, $\frac{36 n^{4}}{n^{5}}$ and for E, $\frac{n^{4}}{n^{5}}$. The standard errors are the under root of the products of common multiplier and specific multiplier. The value of a parameter divided by its standard error was tested against a tabular-t value with $\propto$ degrees of freedom.

\section{RESULTS AND DISCUSSION}

It can be discerned from Table 1 that there were highly significant differences in total glucosinolate, oil and protein contents between the genotypes and locations. The genotype by location interaction $\left(G^{*} L\right)$ was highly significant for oil and protein but was not significant for glucosinolate. There were also significant differences among the six parental lines, and their Fs in all the three traits but not between the two groups in total glucosinolate.

Analysis of variance components by the linear mixed model showed that the additive, dominance and cytoplasmic main effects were highly significant for all the traits (Table 2). The interactions of the latter two components with the locations, however, varied with the traits. The dominance by location interaction, for example, was highly significant for glucosinolate and oil but not for protein contents, and the cytoplasm by location interaction was significant only for oil content. The additive by location interaction components of the variances, on the other hand, were invariably non-significant for all the three traits. The additive components of total glucosinolate, oil and protein contents have, respectively, accounted for 39,35 and $40 \%$ of the genetic variations. The dominance components, account- ing for almost one half of the additive, were in general twice as large as those of the cytoplasmic components. As a consequence of higher levels of contributions of the additive and cytoplasmic components to the total variation, the narrowsense heritabilities of all the traits reached well over $40 \%$.

Table 1. Mean squares of total glucosinolate (GSL), oil and protein contents from the analyses of the six by six diallel crosses of $B$. carinata

\begin{tabular}{lllll}
\hline Source of variation & DF & GSL & Oil & Protein \\
\hline Location $(\times 1000)$ & 1 & $16^{* *}$ & $1.85^{* *}$ & $19.20^{* *}$ \\
Genotype & 35 & $314^{* *}$ & $4.89^{* *}$ & $4.34^{* *}$ \\
$\quad$ Among Parents & 5 & $629^{* *}$ & $12.11^{* *}$ & $8.77^{* *}$ \\
$\quad$ Among Hybrids & 29 & $263^{*}$ & $3.12^{*}$ & $3.51^{*}$ \\
$\quad$ Parents vs Hybrids & 1 & 205 & $19.98^{* *}$ & $6.21^{* *}$ \\
Genotype x Location & 35 & 202 & $5.43^{* *}$ & $4.08^{* *}$ \\
Error & 70 & 209 & 1.17 & 0.69 \\
\hline
\end{tabular}

** and * are significant at 0.01 and 0.05 levels

Table 2 Variance components and heritability of total glucosinolate (GSL), oil and protein contents from the analyses of the six by six diallel crosses of B. carinata.

\begin{tabular}{llll}
\hline Variance component & GSL & Oil & Protein \\
\hline Additive & $330^{* *}$ & $4.22^{* *}$ & $1.58^{* *}$ \\
Dominance & $198^{* *}$ & $2.72^{* *}$ & $0.98^{* *}$ \\
Cytoplasm & $86^{* *}$ & $1.01^{* *}$ & $0.26^{* *}$ \\
Additive x Location & $\mathrm{NS}$ & $\mathrm{NS}$ & $\mathrm{NS}$ \\
Dominance x Location & $81^{* *}$ & $1.71^{* *}$ & $\mathrm{NS}$ \\
Cytoplasm x Location & $\mathrm{NS}$ & $0.41^{* *}$ & $\mathrm{NS}$ \\
Residual & 185 & 2.11 & 1.16 \\
& & & \\
Heritability (narrow-sense) & 0.47 & 0.43 & 0.46 \\
Heritability (broad-sense) & 0.71 & 0.65 & 0.71 \\
\hline
\end{tabular}

** = significant at 0.05 level and NS= not significant.

It is evident from Table 3 that lines 1, 2 and 5 which were originally selected as lowglucosinolate parents had a total glucosinolate content of about $25 \mu$ moles less than those of the two high-glucosinolate lines 3 and 4, which, respectively, produced an average of 88 and $86 \mu$ moles/g of seed. The lowest total glucosinolate content $(55 \mu$ moles) resulted from the cross between lines 3 and 5, which is a reduction of $18 \%$ from the means of the population and $F_{1} s$ and $22 \%$ from the mean of the parents. 
Figure 1 shows that the low-glucosinolate parental lines 1, 2 and 5 still exhibited decreasing additive main effects on total glucosinolate while those of lines 3, 4 and 6 had increasing effects. The additive and cytoplasmic effects of the lines, however, appeared to operate in opposite directions. While the additive effects of lines 1 and 2 reduced glucosinolate by 15 and $10 \mu$ moles/g of seed, their respective cytoplasms increased same by 5 and 15 $\mu$ moles/g of seed. Lines 3 and 6, on the other hand, showed exactly the reverse although with a different magnitude. Lines 4 and 5 did not impart any noticeable cytoplasmic effect on total glucosinolate.

Table 3. Mean glucosinolate, oil and protein contents of the six by six diallel crosses of B. carinata.

\begin{tabular}{|c|c|c|c|c|c|c|c|}
\hline Line & $\begin{array}{l}46 \\
\text { (1) }\end{array}$ & $\begin{array}{l}74 \\
(2)\end{array}$ & $\begin{array}{l}36 \\
(3)\end{array}$ & $\begin{array}{l}51 \\
(4)\end{array}$ & $\begin{array}{l}11 \\
(5)\end{array}$ & $\begin{array}{l}141 \\
\text { (6) }\end{array}$ & Mean \\
\hline & \multicolumn{7}{|c|}{ Glucosinolates ( $\mu$ moles/g seed) } \\
\hline 1 & 61 & 57 & 77 & 69 & 62 & 60 & 64 \\
\hline 2 & 58 & 62 & 76 & 81 & 73 & 63 & 69 \\
\hline 3 & 60 & 69 & 88 & 75 & 55 & 77 & 71 \\
\hline 4 & 57 & 71 & 77 & 86 & 58 & 78 & 71 \\
\hline 5 & 66 & 68 & 56 & 68 & 63 & 61 & 64 \\
\hline 6 & 68 & 83 & 69 & 72 & 61 & 66 & 70 \\
\hline Mean & 62 & 68 & 74 & 75 & 62 & 67 & 68 \\
\hline Parental mean & & & & & & & 71 \\
\hline \multirow[t]{2}{*}{$\mathrm{F}_{1}$ mean } & & & & & & & 67 \\
\hline & \multicolumn{7}{|c|}{ Oil content (\%) } \\
\hline 1 & 46.0 & 48.0 & 45.5 & 46.5 & 44.5 & 47.5 & 46.0 \\
\hline 2 & 46.5 & 45.5 & 45.5 & 44.9 & 44.5 & 46.0 & 45.0 \\
\hline 3 & 47.0 & 46.5 & 42.5 & 43.0 & 44.0 & 46.0 & 45.0 \\
\hline 4 & 45.5 & 45.5 & 45.5 & 41.0 & 45.5 & 43.5 & 44.5 \\
\hline 5 & 44.0 & 45.0 & 45.5 & 43.5 & 40.0 & 45.0 & 43.5 \\
\hline 6 & 47.0 & 45.5 & 44.5 & 43.5 & 45.5 & 44.5 & 45.0 \\
\hline Mean & 46.0 & 46.0 & 44.5 & 43.5 & 44.0 & 45.5 & 45.0 \\
\hline Parental mean & & & & & & & 43.2 \\
\hline \multirow[t]{2}{*}{$\mathrm{F}_{1}$ mean } & & & & & & & 45.3 \\
\hline & \multicolumn{7}{|c|}{ Protein content (\%) } \\
\hline 1 & 27.0 & 29.5 & 30.0 & 29.5 & 29.0 & 30.0 & 29.0 \\
\hline 2 & 29.5 & 31.5 & 31.0 & 29.5 & 30.0 & 30.5 & 30.0 \\
\hline 3 & 30.5 & 31.0 & 32.0 & 30.5 & 30.0 & 31.5 & 31.0 \\
\hline 4 & 30.0 & 30.5 & 30.0 & 30.0 & 28.5 & 30.5 & 30.0 \\
\hline 5 & 30.0 & 29.5 & 28.5 & 30.5 & 28.5 & 29.0 & 29.0 \\
\hline 6 & 31.0 & 30.5 & 32.0 & 30.0 & 29.0 & 32.0 & 30.5 \\
\hline Mean & 29.5 & 30.5 & 30.5 & 30.0 & 29.0 & 30.5 & 30.0 \\
\hline Parental mean & & & & & & & 30.2 \\
\hline $\mathrm{F}_{1}$ mean & & & & & & & 30.0 \\
\hline
\end{tabular}

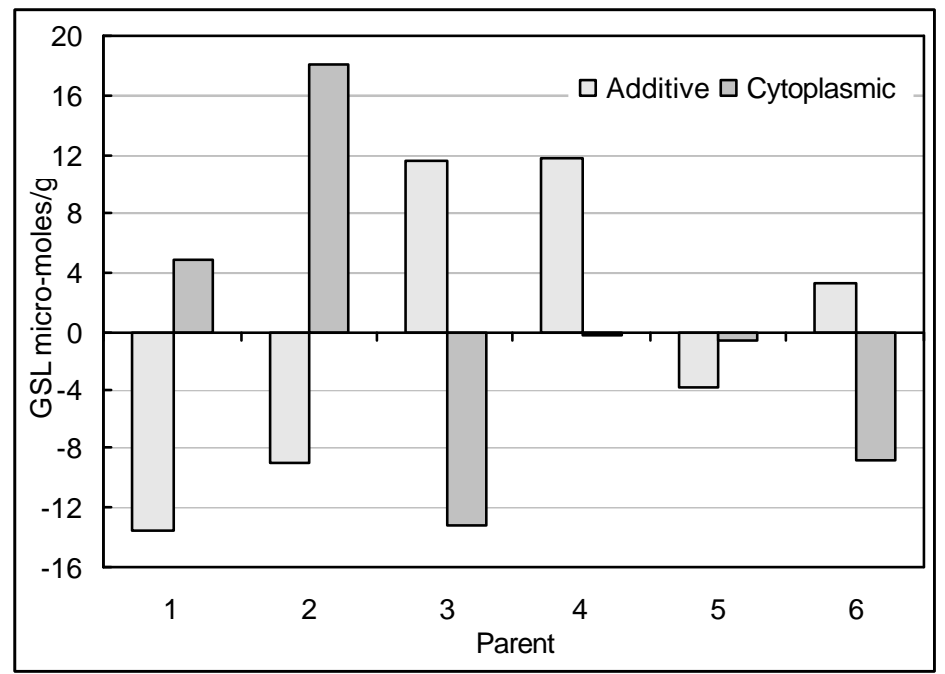

Fig. 1. Additive and cytoplasmic effects of the six parental lines of B. carinata on total glucosinolate content. 
It is discernible from Table 4 that dominance effects on glucosinolate, as determined from the analysis of variance components by the mixed model, were evident both at homozygous $\left(x_{i} * x_{i}\right)$ and heterozygous $\left(x_{i} * x_{j}\right)$ phases. Some specific crosses like, $1 \times 2,3 \times 5$ and $4 \times 6$, showed a considerable amount of dominance effects of reducing the total glucosinolate by up to $40 \mu$ moles/g of seed. Some other crosses, on the other hand, had dominance effects of increasing the trait by a level of $20 \mu$ moles/g of seed (eg., cross $2 \times 3$ ).

Table 4. Dominance effects of the six parental lines of $B$. carinata and their crosses on total glucosinolate (GSL), oil and protein contents.

\begin{tabular}{cccc}
\hline Line/Cross & $\begin{array}{c}\text { GSL } \\
(\mu \text { moles/g) }\end{array}$ & $\begin{array}{c}\text { Oil } \\
(\%)\end{array}$ & $\begin{array}{c}\text { Protein } \\
(\%)\end{array}$ \\
\hline $1^{*} 1$ & -1 & -1.4 & -2.1 \\
$2^{*} 2$ & -13 & -0.9 & 1.3 \\
$3^{*} 3$ & 3 & -2.6 & 1.5 \\
$4^{*} 4$ & 9 & -3.2 & 0.5 \\
$5^{*} 5$ & 5 & -4.0 & 0.1 \\
$6^{*} 6$ & -7 & -1.6 & 1.0 \\
$1^{*} 2$ & -18 & 1.0 & -0.2 \\
$1^{*} 3$ & -1 & 0.8 & 0.3 \\
$1^{*} 4$ & -1 & 1.4 & 1.0 \\
$1^{*} 5$ & 8 & -0.4 & 1.6 \\
$1^{*} 6$ & 2 & 1.4 & 0.7 \\
$2^{*} 3$ & 20 & 0.4 & -0.5 \\
$2^{*} 4$ & -3 & 0.9 & -0.6 \\
$2^{*} 5$ & 12 & 0.9 & 0.1 \\
$2^{*} 6$ & 4 & 0.2 & -0.7 \\
$3^{*} 4$ & 3 & 1.0 & -1.0 \\
$3^{*} 5$ & -37 & 1.7 & -1.4 \\
$3^{*} 6$ & 21 & 1.0 & 0.4 \\
$4^{*} 5$ & 3 & 2.5 & 0.0 \\
$4^{*} 6$ & -9 & -0.8 & -0.6 \\
$5^{*} 6$ & 0 & 2.0 & -1.4 \\
\hline
\end{tabular}

Since the genotype by location interactions were not significant for total glucosinolates, estimates of genetic parameters have been made using combined data following Hayman's method (Table 5). An additive-dominance model could adequately be employed to explain the gene action and estimate the components of variation since the $\mathrm{t}^{2}$-test was not significant and also that the regression coefficient (b) was significantly different from zero but not from one. The dominance by location interaction component was highly significant. The mean degree of dominance $\left(\mathrm{H}_{1} / \mathrm{D}\right)^{0.5}$ was below unity, indicating a clear-cut case of partial dominance of the genes involved. This was further supported by the relative position of the intercept of the regression line, which was 10 units above the origin of the parabola (Fig. 2). The proportion of genes with positive and negative effects $\left(\mathrm{H}_{2} / 4 \mathrm{H}_{1}\right)$, as a measure of the average value of the product of the frequencies of intra-locus alleles over all loci, was 0.09 . This value is much less than the theoretically maximum of 0.25 which could have been attained had there been a symmetrical distribution of increasing and decreasing genes each at a frequency of 0.5 in the parental lines. This asymmetric distribution of the genes with positive and negative effects was also corroborated by the positive value of " $\mathrm{F}$ " which is the parameter measuring the average covariance of additive and dominance effects and thus indicating an excess presence of dominant genes. The ratio $\left.\left.\left[\left(4 \mathrm{DH}_{1}\right)^{0.5}+\mathrm{F}\right) /\left(4 \mathrm{DH}_{1}\right)^{0.5}-\mathrm{F}\right)\right]$ which is given as $\mathrm{Kd} / \mathrm{Kr}$ in Table 5 once again confirmed that there were 2-3 dominant genes for each single recessive gene governing total glucosinolate in the parental lines.

Table 5. Estimates and significances of genetic parameters for total glucosinolate content From the analyses of the six by six diallel cross of B. carinata according to Hayman's (crf Singh and Chaudhary, 1977) method.

\begin{tabular}{lll}
\hline Parameter & Estimate & \pm SE \\
\hline $\mathrm{D}$ & $124^{* *}$ & 23 \\
$\mathrm{H}_{1}$ & $86^{*}$ & 29 \\
$\mathrm{H}_{2}$ & 60 & 53 \\
$\mathrm{~F}$ & 86 & 57 \\
$\mathrm{~b}$ & 0.83 & 0.27 \\
$\mathrm{E}$ & $34^{* *}$ & 0.17 \\
$\left(\mathrm{H}_{1} / \mathrm{D}\right)^{0.5}$ & 0.84 & \\
$\mathrm{H}_{2} / 4 \mathrm{H} \mathrm{H}_{1}$ & 0.09 & \\
$\mathrm{Kd} / \mathrm{Kr}$ & 2.58 & \\
$\mathrm{r}$ & 0.81 & \\
$\mathrm{t}^{2}$ & 1.34 & \\
$\mathrm{~h}^{2}$ (narrow-sense) & 0.40 & \\
\hline
\end{tabular}

The product moment correlation coefficient $(\mathrm{r})$ between parental order of dominance $(\mathrm{Wr}+\mathrm{Vr})$ and parental mean $(\mathrm{Yr})$ was significant $(\mathrm{p} \leq 0.05)$ which is an indication that parents with most increasing genes had the highest value of $\mathrm{Wr}+\mathrm{Vr}$ and thus contained most of the recessive genes. Distribution of the parental lines along the $\mathrm{Vr}-\mathrm{Wr}$ graph (Fig. 2) throws more light on the latter fact. 
Lines 3 and 4 which were the highest-glucosinolate parents possessed each below $25 \%$ of the dominant genes since they occur well in the upper $1 / 4^{\text {th }}$ of the area; while, on the contrary, lines 1 and 5 contained at least $3 / 4^{\text {th }}$ of the dominant genes since they occur in the lower $1 / 4^{\text {th }}$ of the graph. Lines 2 and 6 were of genotypes with more or less symmetrical distribution of the dominant and recessive genes.

The estimations of genetic parameters of total glucosinolate content using both mixed model and Hayman's method are in support of each other that while lines 1 and 5 were found to be lowglucosinolate parental lines, 3 and 4 were highglucosinolate lines. Interestingly, the maximum negative heterosis $(-21 \mu$ moles/g of seed) was obtained from the cross between line 3 , which had the highest per-se performance ( $88 \mu$ moles) and increasing additive, but reducing cytoplasmic effects, and line 5 (63 $\mu$ moles), one of the lowglucosinolate parents with reducing additive as well as cytoplasmic effects. The agreement of the two methods was further corroborated by the similar narrow-sense heritability estimates, which amounted 40\% with Hayman's method and 39\% with the mixed linear model.

Fig. 3 reveals that lines 1 and 2, in addition to their low-glucosinolate characteristic, were also endowed with additive effects of increasing oil content by more than one percent above the population mean, $45 \%$ (Table 3). Lines 4 and 5, conversely, had additive effects of reducing oil by almost the same magnitude. The cytoplasm of these parental lines, however, was characterized differently and the differences were further expounded by interactions with locations (Fig.3). It could also be discerned that, while the cytoplasmic main effects of lines 1 and 3 increased oil content by about one percent, its environmental interaction reduced the gain by half at Kulumsa (location-2). Conversely, the main effect of the cytoplasm of line 2 reduced oil content by one and a half percent, while its interaction revoked the loss to only half a percent at same location. Dominance at homozygous phase reduced oil content very severely ranging from a low of $0.9 \%$ in line 2 to a high of $4 \%$ in line 5 (Table 4).

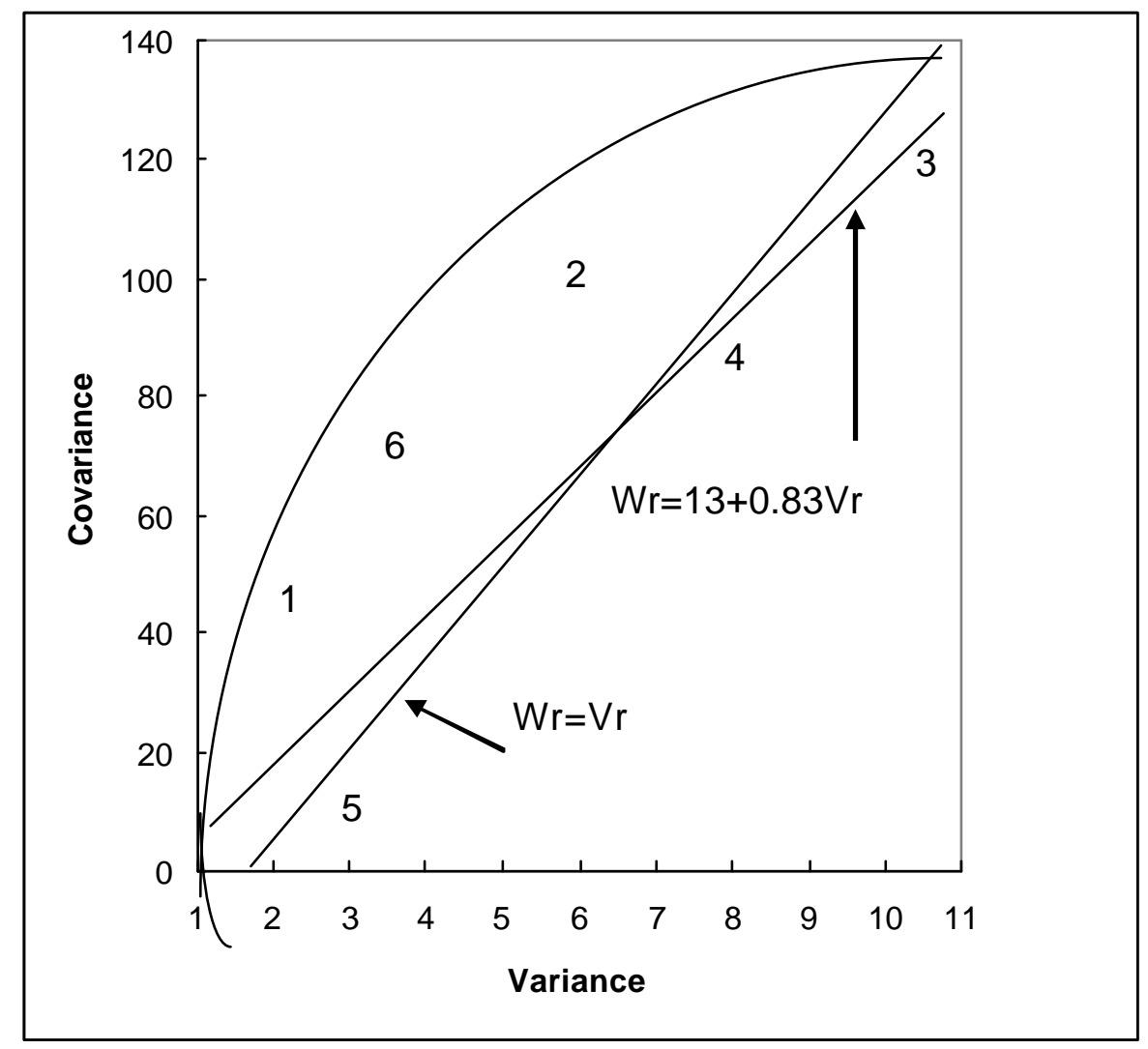

Fig. 2. Variance-Covariance graph of total glucosinolate from the diallel analysis of B. carinata crosses of six parental lines. 


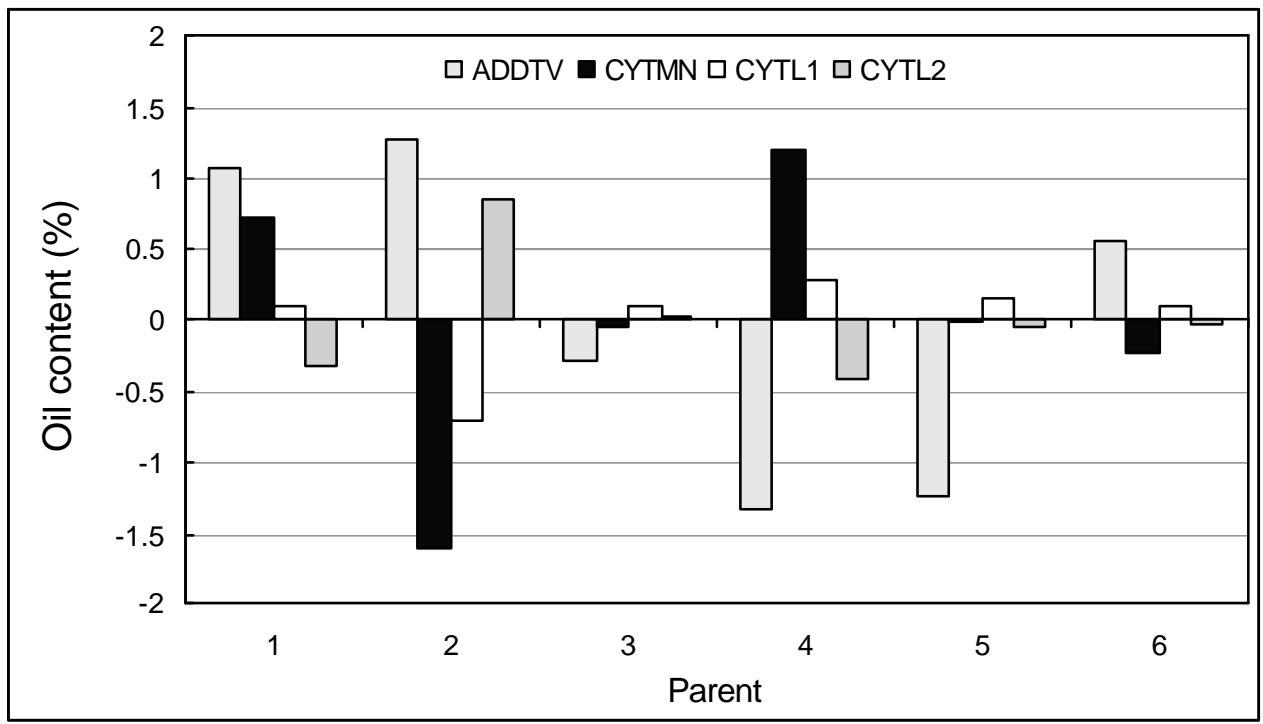

Fig. 3. Additive (ADDTV) and cytoplasmic (CYTMN) main effects and interactions of the latter with locations (CYTL1 and CYTL2) on oil content of the six parental lines of B. carinata.

With protein content, all the main effects of the additive, dominance and cytoplasmic components were significantly important (Table 2). The additive effects of lines 1 and 5 reduced protein by about one percent, while those of lines 2, 3 and 6 increased it by more than half a percent (Fig. 4). The positive additive effects of the latter two lines were further intensified by their cytoplasmic effects of almost same magnitude. Conversely, the positive additive effect of line 2 was slightly diluted by its reducing cytoplasmic effect. The cytoplasm of line 1 aggravated further the reducing effect of its additive effect. It is evident from Table 4 that dominance, both at homozygous and heterozygous phases, was important with the effects ranging from an increase of the trait by more than one percent (homozygous phases of lines 2 and 3 and the cross between lines 1 and 5) to a reduction of the trait by about two percent (line 1 at homozygous phase and the cross between lines 3 and 5) above or below the population mean of $30 \%$ (Table 3 ).

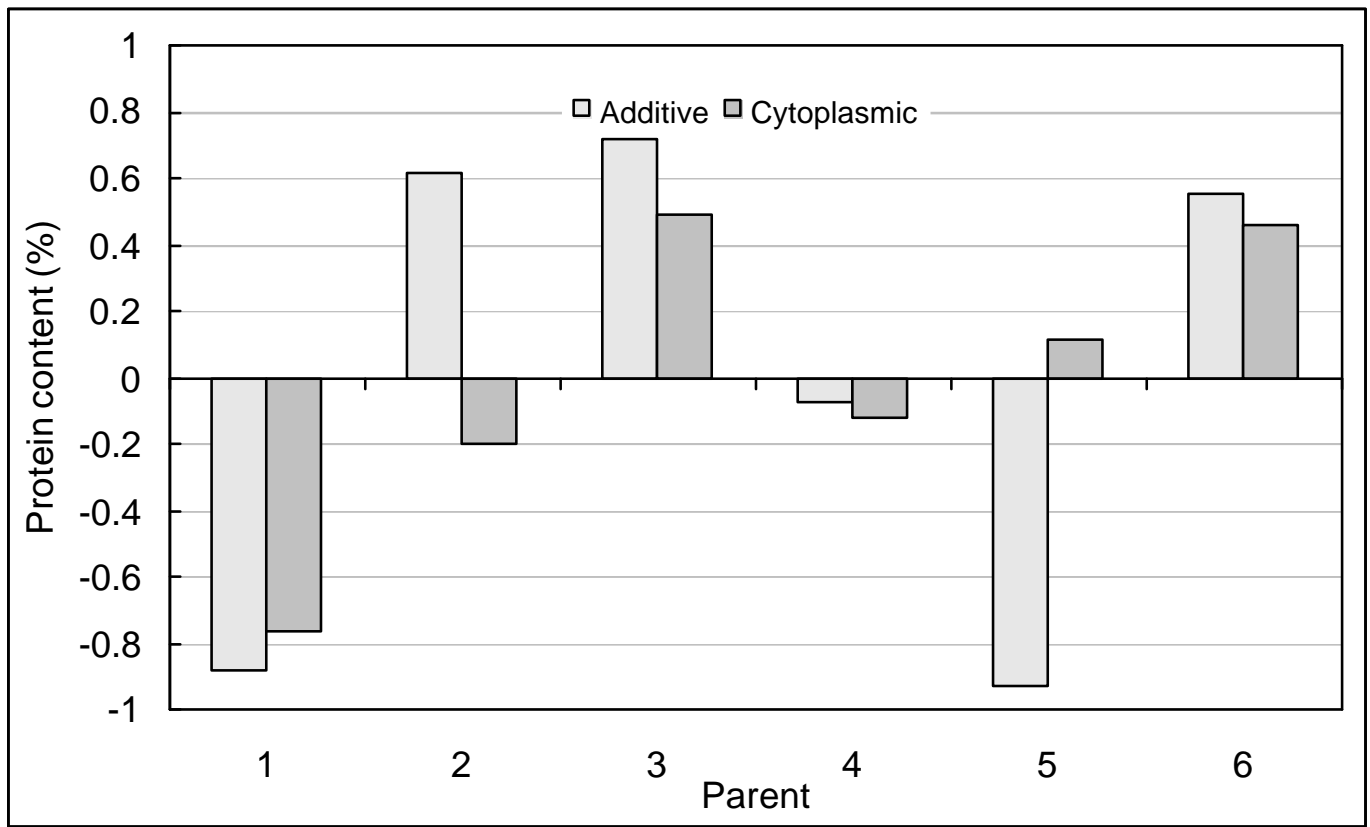

Fig. 4 Additive and cytoplasmic effects of the six parental lines of B. carinata on protein content. 
The results have generally revealed that there were significant differences among the lines used as parents and also among their $F_{1}$ s. With glucosinolate, not only was non-significant the interaction between genotypes and locations, but also remained the lines true to their original class which indicates that they have been stabilized at lower or higher levels of the trait. In all the three traits, although the additive component of the variation constituted relatively the larger part, the dominance and cytoplasmic components also played a significant role in the inter-play of gene action determining the phenotypic values. Environmental influences on these components were at times synergistic or antagonistic. Generally implying that genotypes with lower levels of total glucosinolate or higher levels of oil and/or protein could be fixed by continuous selection from the segregating populations, but due consideration should be given to the type of seed-bearing plant as well as the growing environment. Single-plant selection, in fact has been successfully employed to lower the total glucosinolate in both summer and winter turnips prior to the discovery of lowglucosinolate B. napus cultivar in 1967 (Roebbelen and Thies, 1980b).

Partial dominance generally appeared as the overriding gene action governing all the three traits in the material tested indicating the importance of both additive and non-additive components though gene actions on these traits have been reported differently. For total glucosinolate, for example, Krzymanski (1976) found dominance in B. napus, Yadava et al. (1984) found over-dominance in B. juncea and Paul et al. (1986) found both additive and dominance effects to be important in B. napus. Gene action for oil content has been shown to be addtive in B. napus (Grami and Stefansson, 1977a), sunflower (Fick, 1975) and corn (Poneleit and Bauman, 1970). Chauhan and Singh (1983) in soybean and Trivedi and Mukharjee (1986) in B. juncea, on the other hand, found both additive and non-additive components to be important in controlling oil content. Additive gene action was reported to be important also for protein in B. napus (Grami and Stefansson, 1977a), sunflower (Fick, 1975), sesame (Culp, 1959) and corn (Poneleit and Bauman, 1970). Chauhan and Singh (1983) in soybean and Singh et al. (1984) in forage oat found both the additive and non-additive gene actions to be of significance in controlling protein content. The significant cytoplasmic components noted in this experiment measuring both the reciprocal and other maternal effects which could be persistent cytoplasmic or simply a transient maternal effects, are in support of earlier reports (Roebbelen and Thies, 1980a and b; Magrath and Mithen, 1993), oil and protein in sunflower (Fick, 1975), in corn (Poneleit and Bauman, 1970) and in soybean (Singh and Hadley, 1972) have been found. The severe reductional effect of dominance at homozygous phase on oil content clearly showed that this trait is sensitive to inbreeding depression.

It was also eminent from the present study based on Hayman's analysis that there were several genes involved and the proportion of dominant genes which appeared to have decreasing effects on total glucosinolate was at least twice as many as the recessive genes of counter effects. Results from other studies also showed that several genes control total glucosinolate in brassicas. Kondra and Stefansson (1970) proposed at least 11, Magrath et al. $(1993 ; 1994)$ reported six, and Love et al. (1990) found three, Rücker and Roebbelen (1994) reported 4-5, and Uzunova et al. (1995) suggested, from their RFLP linkage map studies, that at least 4 genes are involved in genetic control of glucosinolate content.

It can be concluded that the additive, dominance and cytoplasmic components of variations and at times their environmental interactions are important in all the three quantitative traits of $B$. carinata. Given the conditions of predominantly occurring additive component of variation, coupled with the high levels of narrow-sense heritability estimates, it would be very likely that genotypes with considerably lower levels of total glucosinolate and higher levels of oil and protein contents could be developed by continuous selection from the segregating generations of the various crosses.

\section{ACKNOWLEDGEMENTS}

We thank Dr. Leonardo Velasco for his help in developing calibration equations for NIRS and for his suggestions at the proposal phase of the experiment. Thanks are due to Professor Dr. Jun Zhu for providing computer programs for the linear mixed model analysis of diallel cross and environmental interactions. The first author gratefully acknowledges the financial support of the German Academic Exchange Service (DAAD). 


\section{REFERENCES}

1. Becker, H.C., Löptien, H. and Roebbelen, G. (1999). Breeding: An overview. In: Biology of Brassica coenospecies, pp. 413-460, (Gomez-Campo, C., ed.) Elsevier, Science BV, Amsterdam.

2. Bell, J.M. (1993). Factors affecting the nutritional value of canola meal: a review. Can. J. Anim. Sci. 73:679-697.

3. Bell, J.M. and Shires, A. (1982). Composition and digestibility by pigs of hull fractions from rapeseed cultivars with yellow or brown seed coats of Brassica campestris and Brassica napus. Can. J. Anim. Sci. 62:557-565.

4. Bell, J.M. and Williams, K. (1953). Growth depressing factors in rapeseed oil meal. Can. J. Agric. Sci. 33:201-209.

5. Bourdon, D. and Aumaitre, A. (1990). Lowglucosinolate rapeseeds and rapeseed meal: Effect of technological treatments on chemical composition, digestible energy content and feeding value for growing pigs. Animal Sci. and Technol. 30:175-191.

6. Chauhan, V.S. and Singh, B.B. (1983). Genetic analysis of protein and oil content in soybean. Indian J. Agric. Sci. 53:634-637.

7. Culp, T.W. (1959). Inheritance and association of oil and protein content and seed coat type in sesame (Sesamum indicum L). Genetics 44:897909.

8. Downey, R.K. (1990). Canola: A quality Brassica oilseed. In: Advances in New crops, pp. 211-217, (Janick, J. and Simon, J.E., eds). Timber Press, Portland OR, USA.

9. Fick, G.N. (1975). Heritability of oil content in sunflowers. Crop Sci. 15:77-78.

10. Gomez-Campo, C. and Prakash, S. (1999). Origin and domestication of the Brassica. In: Biology of Brassica Coenospecies, pp. 33-58, (GomezCampo, C., ed.) Elsevier, Amsterdam.

11. Gomez, K.A. and Gomez, A.A. (1984). Statistical Procedures for Agricultural Research. John Wiley and Sons, New York, 680 pp.

12. Grami, B. and Stefansson, B.R. (1977a). Gene action for protein and oil content in summer rape. Can. J. Plant Sci. 57:625-631.

13. Kjaer, A. (1976). Glucosinolates in the cruciferae. In: The Biology and Chemistry of the Cruciferae, pp. 207-219, (Vaughan, J.G., Macleod, A.J. and Jones, B.M.G., eds). Academic Press, London.

14. Kondra, Z.P. and Stefansson, B.R. (1970). Inheritance of major glucosinolates of rapeseed Brassica napus) meal. Can. J. Plant Sci. 50:643-647.

15. Krzymanski, J. (1976). Rapeseed breeding for better oil and meal quality in Poland. In: Proceedings of the $4^{\text {th }}$ International Rapeseed Conference, pp. 4956. GCIRC, Poznan, Poland.

16. Love, H.K., Rakow, G., Raney, J.P. and Downey, R.K. (1990). Genetic control of 2-propenyl and 3butenyl glucosinolates synthesis in mustard. Can. J. Plant Sci. 70:425-429.

17. Madson, E. (1976). Nuclear Magnetic Resonance Spectrometry: A method of determination of oil content in rapeseed oil. JAOCS 53:467-469.

18. Magrath, R. and Mithen, R. (1993). Maternal effects on the expression of individual aliphatic glucosinolates in seeds and seedlings of Brassica napus. Plant Breeding 111:249-252.

19. Magrath, R., Herron, C., Giamoustaris, A. and Mithen, R. (1993). The inheritance of aliphatic glucosinolates in Brassica napus. Plant Breeding 111:55-72.

20. Magrath, R., Bano, F., Morgen, M., Parkin, I., Sharp, A., Lister, C., Dean, C., Turner, J., Lydiate, D. and Mithen, R. (1994). Genetics of aliphatic glucosinolates. I: Side chain elongation in Brassica napus and Arabidopsis thaliana. Hered. 72:290-299.

21. Paul, N.K., Johnston, T.D. and Egles, C.F. (1986). Inheritance of S-Methyl-L-cysteinesulfoxide and thiocyanate contents in forage rape (Brassica napus). Theor. Appl. Genet. 72:706-709.

22. Poneleit, C.G. and Bauman, L.F. (1970). Diallel analysis of fatty acids in corn (Zea mays L.). Crop Sci. 10:338-341.

23. Roebbelen, G. (1981). Breeding for low content of glucosinolates in rapeseed. In: World Crops: Production and Utilization of Protein in Oilseed Crops, pp. 91-106, (Bunting, E.S., ed.) Martinus Nijhoff Publishers, the Netherlands.

24. Roebbelen, G. and Thies, W. (1980a). Biosynthesis of seed oil and breeding for improved oil quality of rapeseed. In: Brassica Crops and Wild Allies: Biology and Breeding, pp. 253-283, (Tsunoda, S., Hinta, K. and Gomez-Campo, C., eds). Japan Scientific Societies Press, Tokyo.

25. Roebbelen, G. and Thies, W. (1980b). Variation in rapeseed glucosinolates and breeding for improved meal quality. In: Brassica Crops and Wild Allies: Biology and Breeding, pp. 285-299, (Tsunoda, S., Hinta, K. and Gomez-Campo, C., eds). Japan Scientifi c Societies Press, Tokyo.

26. Rücker, B. and Roebbelen, G. (1994). Inheritance of total and individual glucosinolate contents in seeds of winter oilseed rape (Brassica napus L.). Plant Breeding 113:206-216.

27. Sarwar, G., Bell, J.M., Sharby, T.F. and Jones, J.D. (1981). Nutritional evaluation of meals and meal fractions derived from rape and mustard seed. Can. J. Anim. Sci. 61:719-733.

28. Seegler, C.J.P. (1983). Oil Plants in Ethiopia: Their Taxonomy and Agricultural Significance. Center 
for Agricultural Publishing and Documentation, PUDOC, Wageningen, the Netherlands, 122 pp.

29. Shigesaburo-Tsunoda, S. (1980). Eco-physiology of wild and cultivated forms in Brassica and allied genera. In: Oil Crops of the World, pp. 109-120, (Roebbelen, G., Downey, R.K. and Ashri, A., eds). McGraw-Hill, New York.

30. Singh, A.S., Solanki, K.R., Jatasra, D.S. and Kishor, C. (1984). Genetic analysis of protein in forage oat. Indian J. Agric. Sci. 54:908-911.

31. Singh, R.K. and Chaudhary, B.D. (1977). Biometrical Methods in Quantitative Genetic Analysis . Kalyani Publishers, New Delhi, 304 pp.

32. Singh, L. and Hadley, H.H. (1972). Maternal and cytoplasmic effects on seed protein content in soybeans, Glycine max (L.) Merril. Crop Sci. 12:583-585.

33. Sorensen, H. (1981). New methods of quantitative analysis of glucosinolates. In: World Crops: Production and Utilization of Protein in Oilseed Crops, pp. 107-123, (Bunting, E.S., ed.) Martinus Nijhoff Publishers, the Netherlands.

34. Trivedi, H.B.P. and Mukharjee, B.K. (1986). Genetic parameters and their implication in breeding high-oil varieties of Indian mustard. Indian J. Agric. Sci. 56:10-14.
35. Underhill, E.W. (1980). Glucosinolates. In: Secondary Plant Products, pp. 493-511, (Bell, E.A. and Charlwood, B.V., eds). Springler, Berlin.

36. Utz, H.F. (1991). PLABSTAT: A Computer Program for Statistical Analysis of Plant Breeding Experiments. University of Hohenheim, Stutgart, Germany.

37. Uzunova, M., Ecke, W., Weisslede, K. and Roebbelen, G. (1995). Mapping the genome of rapeseed (Brassica napus L.) I. Construction of an RFLP linkage map and localization of QTLs for seed glucosinolate content. Theor. Appl. Genet. 90:194-204.

38. Velasco, L., Fernandez-Martinez, J. and De Haro, A. (1995). The applicability of NIRS for estimating multiple seed quality components in Ethiopian mustard. In: Proceedings of the $\mathrm{gh}^{\mathrm{h}}$ International Rapeseed Conference, pp. 867-869. GCIRC, Cambridge, UK.

39. Yadava, T.P., Kumar, P., Gupta, S.K. and Thakral, S.K. (1984). Genetic architecture of allylisothiocy anate in Indian mustard. Indian J. Agric. Sci. 54:546-549.

40. Zhu, J. and Weir, B.S. (1994). Analysis of cytoplasmic and maternal effects I: A genetic model for diploid plant seeds and animals. Theor. Appl. Genet. 89:153-159. 